\title{
Gilberto Marzano*
}

\section{Crowd-Based Applications and Societal Challenges}

\begin{abstract}
SUMMARY
The spread of mobile technology and ubiquitous connectivity have opened great possibilities for the implementation of applications that leverage data generated by normal users' interactions on the web. As a consequence, there is a growing interest in crowd-based applications, namely those programs that involve people in a participatory or opportunistic way.

In many cases, data can be gathered automatically without user intervention and, in some cases, even without their explicit knowledge. The possibility to elude a users' awareness fosters concerns regarding the potential risks hidden inside crowd-based applications. These applications might compromise the privacy of citizens, whilst data collected by them might be used to manipulate people's opinions.

The governance of technology is a controversial area, and there is a wide array of different positions on the matter. There are those who dogmatically argue the positive value of technology, while others interpret the ongoing digital advancements as a dystopian menace. This article focuses on crowd-based applications, highlighting some societal challenges and risks that they may present.

Technology runs so fast that it is challenging to keep pace with the changes brought by the digital revolution. However, an effort is required to extend the depth of digital knowledge of citizens and involve them in the use of the new technologies, and in this endeavor, greater knowledge is an essential step in any critical process.
\end{abstract}

Keywords: citizens' privacy, crowd-based application, crowdsourcing, crowdsensing, citizensensing, societal challenges.

* Correspondence Address: Gilberto Marzano, Laboratory of Pedagogical Technologies at the Research Institute of Regional Studies (REGI), Rezekne Academy of Technologies (Rēzeknes Tehnologiju Akadēmija), Latvia, Atbrivosanas aleja 115, Rezekne, LV 4601, Latvia. E-mail: gilberto.marzano@rta.

Rezekne Academy of Technologies, Spoleczna Akademia Nauk, Łódź, Poland 


\section{Introduction}

Nowadays, ubiquitous connectivity has become the prevailing reality, and mobile apps are mushrooming exponentially. An ever-wider variety of disparate mobile applications provide users with every type of information and service, effective control of devices, and even proactive assistance.

The use of digital media encompasses every aspect of life, and its influence continues to grow. People of every age and social, economic, professional, and educational class are exchanging and sharing a massive quantity of data through social networks, particularly through smartphones. Recent statistics show that more than 3 billion people around the world use social media every month, with 9 out of 10 of those users accessing their chosen platforms via mobile devices (Figure 1).

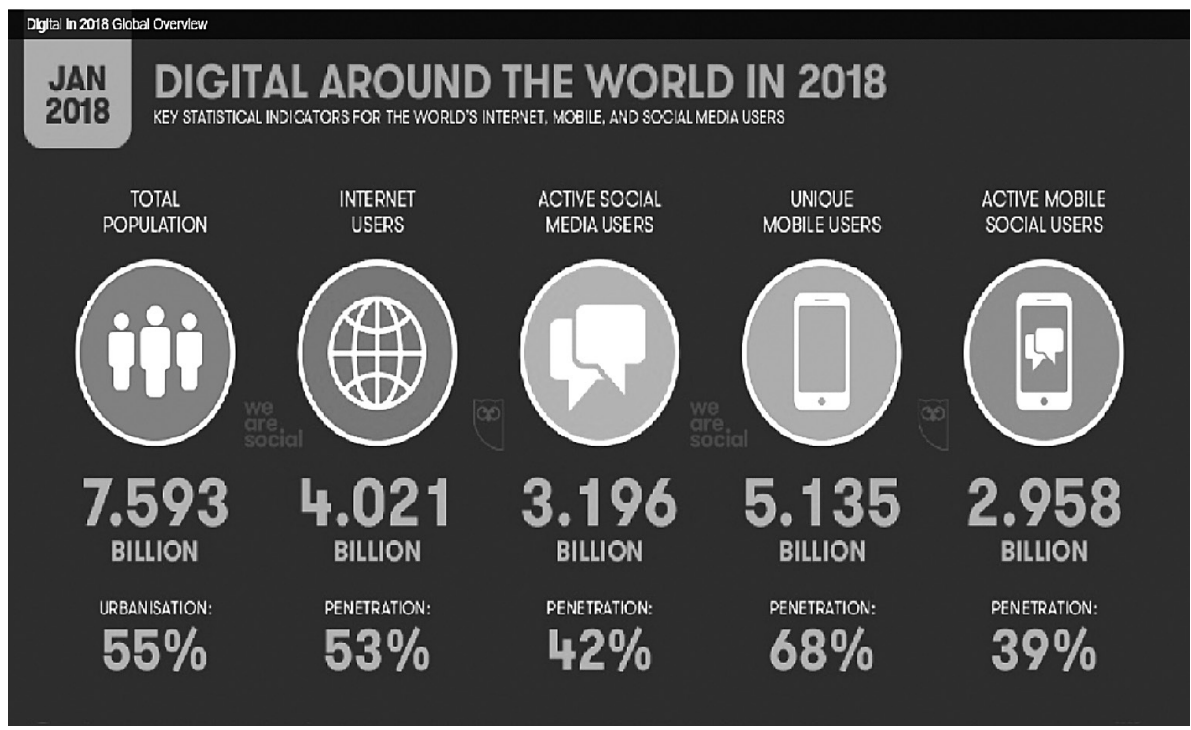

Figure 1. Global digital overview in 2018 (source: We Are Social, 2018; https://wearesocial.com/it/ blog/2018/01/global-digital-report-2018).

In the last few years, as a consequence of the advent of free Wi-Fi and increasingly affordable internet connections, the number of crowd-based applications has exploded. These applications share the common feature of making use of the internet and smart devices in order to involve human and artificial intelligence in the performance of a multiplicity of more or less complex tasks. 


\section{Crowd-based applications}

Crowdsensing, crowdfunding, and crowdsourcing represent the three primary sectors of crowd-based applications.

Crowdsensing is a paradigm that involves ordinary people as participants in a sensing task ${ }^{1}$. Mobile crowdsensing encompasses the notion of participatory and opportunistic sensing. For instance, people are asked to sense and transmit data through their smartphones to a system that collects and processes it for purposes such as traffic optimization, security, sustainable energy management, and various other uses.

Participatory sensing refers to applications where users are directly contacted and asked to provide their data spontaneously. Instead, opportunistic sensing applications use data made available by users via the activities they are involved in, such as posting content on social networking platforms.

Crowdfunding is a crowd-based paradigm that encompasses various types of fundraising that can range from collecting donations to selling equity stakes via the internet. According to Belleflamme, Lambert, and Schwienbancher²:

"Crowdfunding involves an open call, mostly through the Internet, for the provision of financial resources either in form of donation or in exchange for the future product or some form of reward to support initiatives for specific purposes".

Finally, crowdsourcing represents the most diffused form of crowd involvement. Although there is no precise definition of the term, it is broadly agreed that crowdsourcing can be utilized to design initiatives and practices aimed at performing an online distributed problem-solving ${ }^{3,4}$. Crowdsourcing involves the outsourcing of a task, by a company or an institution, to an undefined (and generally large) network of people in the form of an open calls.

1 Mota, Vinicius F., Silva, Thiago H., Macedo, Daniel F., Ghamri-Doudane, Yacine and Nogueira, José M. (2018), Towards scalable mobile crowdsensing through device-to-device communication, Journal of Network and Computer Applications, 122, 99-106.

2 Belleflamme, Paul, Lambert, Thomas and Schwienbacher, Armin (July 9, 2013), Crowdfunding: Tapping the Right Crowd, Journal of Business Venturing, https://ssrn.com/abstract=1836873 (accessed: 13 February 2020), 8.

3 Brabham, Daren C. (2008), Moving the crowd at iStockphoto: The composition of the crowd and motivations for participation in a crowdsourcing application, First Monday, 13(6), https://firstmonday.org/article/\%20 view/2159/1969 (accessed: 13 February 2020).

4 Marzano, Gilberto and Hadzialic, Sabahaudin (2018), Crowd participation in urban decision making and planning: an extensive urban crowdsourcing literature review, in: Conference: XVII International Conference Trends, Technological Innovation, and Digitalization in Transport, Ecology, and Logistics in Sustainable Development Functions, Travnik, 160-168.

5 Howe, Jeff (2006), The rise of crowdsourcing, Wired magazine, 14(6), pp. 1-4. 
Several studies have investigated crowdsourcing applications in different contexts that include business and social innovation, as well as citizensourcing ${ }^{6}$.

The term "citizensourcing" has been coined to describe the use of digital technologies by governmental authorities for gathering and organizing contributions from a multitude of non-professional individuals in order to obtain innovative solutions, ideas, suggestions, and advice ${ }^{7,8}$.

Moreover, citizensourcing represents a new opportunity for the involvement of citizens in governance and public policy. Applications have been suggested for the direct involvement of citizens in public decision making, leading to a new participatory format of public administration functioning, ${ }^{9}$.

In fact, public participation may assume many forms. It could be a formal process ruled by a public institution or an initiative led by citizens. Public participation in decision making can be viewed as a problem-solving process (Figure 2). In this perspective, citizens can be involved in evaluating public choices through crowdsourcing processes.

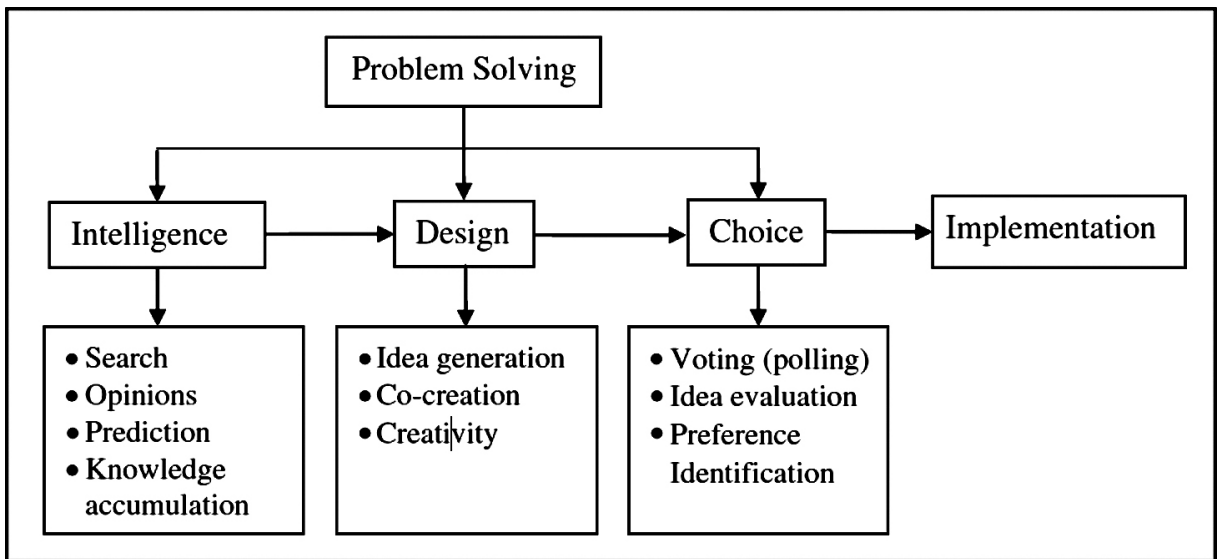

Figure 2. Crowd involvement in a problem-solving process

6 Hossain, Mokter \& Kauranen, Ilkka (2015), Crowdsourcing: a comprehensive literature review, Strategic Outsourcing: An International Journal, 8(1), 2-22.

7 Loukis, Euripidis, Charalabidis, Yannis and Androutsopoulou, Aggeliki (August 2015), Evaluating a Passive social media citizensourcing innovation, In International Conference on Electronic Government, 305-320, Springer, Cham.

8 Thapa, Basanta E., Niehaves, Bjorn, Sedel, Claudius E., \& Plattfaut, Ralf (2015), Citizen involvement in public sector innovation: Government and citizen perspectives, Information Polity, 20(1), 3-17.

9 Tamilin, Andrei, Carreras, Iacopo, Ssebaggala, Emmanuel, Opira, Alfonse and Conci, Nicola (September 2012), Context-aware mobile crowdsourcing, in: Proceedings of the 2012 ACM Conference on Ubiquitous Computing, 717-720.

10 Zhilin, Sergei., Klievink, Bram, and de Jong, Martin (2019), Community Self-Governance in the Smart City: Towards a Typology, in: E-Participation in Smart Cities: Technologies and Models of Governance for Citizen Engagement, Springer, Cham, 81-97. 
Citizens may be involved in evaluating ideas (or performance) and analyzing the alternatives in order to solve urban problems such as transport schemes, pedestrian areas, public mobility, waste treatment, and so on. Moreover, public administrations may collect the crowd's preferences before making decisions on welfare, health-care priorities, and other financial matters.

It has been observed that the motivation to participate in crowdsourcing activities comes from a mix of intrinsic and extrinsic factors ${ }^{11}$. Extrinsic factors can include compensation and/or public recognition, whilst intrinsic factors are individual desires and/or personal satisfaction, similar to the desires/satisfaction of a hobbyist.

Citizensourcing, however, may also involve an additional type of motivation that is neither intrinsic nor extrinsic but incidental when it is indirect or opportunistic. This is the case with citizens who make use of free applications managed by governmental institutions and agree that their data can be used for the enhancement of their community's livability.

Some requests that a municipality could submit to citizens are in regard to:

- Reporting dysfunctions, maintenance interventions, etc.

- Finding solutions to problems, such as how to decongest traffic in a particular area, how to organize care services, how to improve waste collection, etc.

- Gathering opinions concerning cultural activities, social policies, etc.

\section{Operative and technical issues of citizensourcing applications}

The main operative issue is the definition of the citizensourcing model. It is necessary to integrate various exigencies while the specificity of the mobile environment imposes a framework of short and rapid communicative interactions. Furthermore, issues for which a municipality would seek to involve citizens might well require complex evaluations and articulated responses. The primary problem, however, is how to allow interacting collaborative processes within the community.

There are many examples of the use of citizensourcing to receive input on ameliorating services, especially to gather ideas for improving functions and services related to urban planning and infrastructure optimization ${ }^{12,13,14}$.

11 Zheng, Haichao, Li, Dahui, \& Hou, Wenhua (2011), Task design, motivation, and participation in crowdsourcing contests, International Journal of Electronic Commerce, 15(4), 57-88.

12 Schmidthuber, Lisa and Hilgers, Dennis (2018), Unleashing innovation beyond organizational boundaries: exploring citizensourcing projects, International Journal of Public Administration, 41(4), 268-283.

13 You, Linlin, Motta, Gianmario, Liu, Kaixu, and Ma, Tianyi (2016), City feed: A pilot system of citizensourcing for city issue management, ACM Transactions on Intelligent Systems and Technology (TIST), 7(4), 1-25.

14 Pedersen, Jay, Kocsis, David, Tripathi, Abhishek, Tarrell, Alvin, Weerakoon, Aruna, Tahmasbi, Nargess, ... and De Vreede, Gert J. (January 2013), Conceptual foundations of crowdsourcing: A review of IS research, in: 2013 
The most common means adopted for receiving input from citizens is a surveylike approach. People are asked to state their personal perceived importance of a given issue according to a seven-point Likert scale ranging from 1 to 7 (1= "Not at all important", 2="Low importance", 3="Slightly important", 4="Neutral", 5="Moderately important", 6="Very important", 7="Extremely important").

However, citizensourcing applications may put the privacy of citizens as well as societal governance at risk. It is generally known that messages posted on social networks, browsing history, and web searches carried out by search engines can be used for profiling users ${ }^{15,16}$.

The issue of the trading of personal data by the major social networks and search engine providers for the purposes of direct marketing and/or sales promotion has long been reported, investigated, and denounced ${ }^{17,18}$.

Moreover, the analysis of people's behavior on the web may be exploited to influence their political choices. An elite that holds power can reap benefits from the many who innocently share personal information in their interpersonal communications. In this regard, the case of Cambridge Analytica, a firm specialized in Big data and advanced psychographic analysis, was particularly resounding ${ }^{19}$.

Nowadays, advances in Big data analytics and data mining have made the analysis of web content increasingly sophisticated, whilst the advent of the Internet of Things have greatly multiplied the risks for privacy.

Of course, the violation of privacy is a crime that does not depend on digital technologies, but the very nature of the web can devastatingly amplify its effects. The distorted and fraudulent use of users' personal data should not, however, invalidate the positive benefits that can be gained from such analysis whilst, obviously, fully respecting the user's right to privacy.

46th Hawaii International Conference on System Sciences, 579-588. IEEE.

15 Ludington, Sarah (2006), Reining in the data traders: A tort for the misuse of personal information, Md. L. Rev., 66, 140., https://digitalcommons.law.umaryland.edu/cgi/viewcontent.cgi?referer=https://scholar.google. com/\&httpsredir=1\&article $=3291 \&$ context $=\mathrm{mlr}$ (accessed: 23 February 2020).

16 Bennett, Colin J. and Raab, Charles D. (2017), The governance of privacy: Policy instruments in global perspective, Routledge.

17 Schwartz, Paul M. (2004), Property, privacy, and personal data, Harvard Law Review, 2056-2128.

18 Acquisti, Alessandro, Taylor, Curtis and Wagman, Liad (2016), The economics of privacy, Journal of Economic Literature, 52 (2), 442-492.

19 Timberg, Craig \& Hamburger, Tom (March 25, 2018), Former Cambridge Analytica workers say firm sent foreigners to advise U.S. campaigns, Washington Post, https://www.washingtonpost.com/politics/formercambridge-analytica-workers-say-firm-sent-foreigners-to-advise-us-campaigns/2018/03/25/6a0d7d90-2fa2-11e8911 f-ca7f68bff0fc_story.html?utm_term=.420bc7a15e33 (accessed: 13 February 2020). 
Indeed, throughout history, people have greatly suffered from manipulation due only to their fascination with charismatic leaders and oligarchic groups. This happened well before and irrespective of the rise of social media. If anything, nowadays, social media makes manipulation more evident and, potentially, allows for disseminating multiple as well as divergent opinions.

A further element of reflection arises from the relationship between technology and decision-making processes.

\section{Challenges in decision making}

Crowd-based participation opens several socio-political and ethical questions.

Are ordinary people's activities on the internet a form of public participation?

In this regard, how can we defend from the participatory tyranny of social media?

How can we safeguard the interests of minorities in citizensourcing decision-making processes?

The main issues of internet-based participation can be synthesized as follows:

- The reliability and transparency of the participatory process;

- Their vulnerability to manipulation;

- New forms of tyranny based on the consensus obtained through social media.

Furthermore, there is a question concerning responsibility. What is the responsibility of decision-makers in crowd-based participatory processes? They could, for instance, shift the blame by transferring responsibility for a problematic decision to the crowd. The question of responsibility in crowd-based participatory processes represents a new challenging scope for investigation.

The use of social media in public participation should entail a re-thinking of decision making in light of the technological revolution ${ }^{20}$. For example, a new generation of multicriteria tools should be experimented with a view to improving the evaluation of citizensourcing and increasing the transparency of crowd-based decision processes.

There is, however, a central problem that should be considered and analyzed. It concerns an issue that is intrinsic to the use of digital technologies to support decision making, and regards the unpredictability of the individual's control over

20 Puaschunder, Julia M. (April 2018), Nudgital: Critique of behavioral political economy, in: Proceedings of the 9th International RAIS Conference on Social Sciences and Humanities, 87-117, https://www.ceeol.com/search/ chapter-detail?id=661825 (accessed: 11 February 2020). 
those technologies and the disruptive influence this can have. The automation of decision making may, in fact, hold unexpected risks and, sometimes, it is not wise to automate tasks just because it is possible to do so. Indeed, although machine performance is superior, in certain respects, to human abilities, software applications are not always inherently reliable ${ }^{21}$.

There is a difference between societal decisions and decisions transferred to a machine in a productive context. Nevertheless, the notion of augmented cognition can be useful to introduce a general consideration of responsibility in crowd-based decision making.

Researchers involved in augmented cognition well know the question of the reliability of automatic decision making. Augmented cognition is a form of human-systems interaction in which a tight coupling between user and computer is achieved via physiological and neurophysiological sensing of a user's cognitive state ${ }^{22,23}$.

The primary goal of the Augmented Cognition field is to research and develop technologies that are capable of extending the information management capacity of individuals through computing technologies. Augmented Cognition research focuses on accelerating the production of novel concepts in human-system integration. It includes the study of methods for addressing cognitive bottlenecks (e.g., limitations in attention, memory, learning, comprehension, visualization abilities, and decision making) via technologies that assess the user's cognitive status in real-time.

In the light of augmented cognition, one can argue that a machine never makes a decision alone. Intelligent applications process the data they are expected to use and, through algorithms created by human beings, produce outputs in the form of data. To transform this data into a decision, a further step is necessary, namely, the activation of the decision. This activation may be automatic or not. In the first case, the responsibility for the decision lies with whoever established that the algorithm result must be applied. In the second case, instead, the responsibility lies with the decision-maker who accepts the algorithm result. There is, ultimately, always a decision-maker, albeit in the first case, they hide behind the alleged certainty of the algorithm.

21 Kruse, Amy A., and Dylan D. Schmorrow (2005), Session overview: Foundations of augmented cognition, Foundations of augmented cognition, 441-445.

22 Schmorrow, Dilan D. and Fidopiastis, Cali M., eds., (2018), Augmented Cognition: Intelligent Technologies: 12th International Conference, AC 2018, Held as Part of HCI International 2018, Las Vegas, NV, USA, July 1520, 2018, Proceedings (Vol. 10915), Springer.

23 Stanney, Kay M., Schmorrow, Dylan D., Johnston, Matthew, Fuchs Sven, Jones, David, Hale, Kelly S., Ahmad, Ali and Young, Peter (2009), Augmented cognition: An overview, Reviews of human factors and ergonomics, 5(1), $195-224$. 


\section{An underlying problem}

The spread of intelligent algorithms throws open an underlying problem.

What if the decision-making system is based on analyzing the popular mood? Or rather, how do we view a decision that is presented as the result of the people's will?

We can approach this problem from two different points of view, the philosophical or the technical. In either case, however, the main question to address is the same. It concerns the issue of responsibility in decision making.

Taking inspiration from the famous book "Escape from freedom" by Fromm, the problem can be reformulated as one of "escape from responsibility". How can we prevent the escape from responsibility on the part of decision-makers?

Moral philosophy, or ethics, essentially treats decision-making as a normative matter. Good decisions depend on good values. Accordingly, objective and concrete moral truths and values should guide human beings to make good decisions. There is broad consensus among moral philosophers that man should use reason in determining these permanent values. In Platonic tradition, ethical values are something implanted in the minds of human beings (Irwin, 2020). This notion influenced various moral thinkers over the centuries. A pillar of ethics was also the incontrovertible existence of moral laws that, based on permanent ethical values, are universal and eternal, in just the same way as natural laws. This concept was a result of Enlightenment rationalism and underlies the Kantian categorical imperative. Kantian ethics supposes that an ethical proposition can be evaluated as being either true or false based on moral laws and, furthermore, claims that moral laws should apply to all people regardless of their interests and desires ${ }^{24}$. Many philosophers share a belief in this rational perspective and the principle of universalization.

Habermas, claiming his theory of discourse as a descendant of Kantian ethics, argued that moral laws should be based on communication between people who discuss their interests and intentions so that all can understand and be aware of them ${ }^{25}$. Even Marx was influenced by Kant in this respect, formulating the theory that ethics is the product of a deterministic historical process. After his death, Engels tried to overcome the inconsistency of Marx's view that morality serves the interest of the ruling class. Engels presumed a classless society based on a truly human morality that serves the interests of all human beings ${ }^{26}$.

24 Kant, Immanuel (2001), Lectures on ethics (Vol. 2), Cambridge University Press.

25 Clement, Grace (1989), Is the Moral Point of View Monological or Dialogical?: The Kantian Background of Habermas's Discourse Ethics, Philosophy Today, 33(2), 159-173.

26 McCarthy, George E. (2017), Marx and Social Justice: Ethics and Natural Law in the Critique of Political Economy, Brill. 
A compendious survey of moral philosophy from its early roots to recent times can be found in Warnock's essay ${ }^{27}$. This is useful for garnering a basic understanding of the main issues in moral philosophy. Recently, autonomy has become one of the central concepts in contemporary ethics and has generated a new debate over its nature and value ${ }^{28}$.

This said, this article would seek to abstain from any such philosophical discussion. Moral philosophy is a matter for philosophers who, using the philosophical methodology, are interested in systematizing, defending, and recommending concepts of right and wrong behavior.

This article, instead, aims only to highlight the aspect of responsibility in decision making from a purely technical standpoint. The central question, in fact, is "how does moral consensus acquire legitimacy in a society that encompasses diverse value systems?"

Our interest is in supporting the decisions made, regardless of whether the actual decision-maker is a human being or an algorithm. For this purpose, the crucial issue is the implementation of decision processes that are transparent and demonstrate the responsibility of decision-makers. The participatory multicriteria analysis offers a means that can support transparency and explicit responsibility ${ }^{29}$. We can realize decision support systems that consider the contributions of different stakeholders and help them to show the criteria underlying the decisions they reach.

In this regard, the evidence-based understanding of the implications of an algorithm's application is necessary before its large-scale use ${ }^{30}$. Unfortunately, determining the potential and actual ethical impact of an algorithm is no easy matter. Indeed, identifying the human subjectivity of an algorithm can require the analysis of its design and development processes. Furthermore, the impact also depends on the application domain.

27 Warnock, Geoffrey J. (1974), Contemporary moral philosophy, in: Hudson William D. New Studies in Ethics, Palgrave, 421-503.

28 Taylor, James S., eds., (2005), Personal autonomy: New essays on personal autonomy and its role in contemporary moral philosophy, Cambridge University Press.

29 Yu, Po-Lung (2013), Multiple-criteria decision making: concepts, techniques, and extensions (Vol. 30), Springer Science \& Business Media.

30 Mittelstadt, Brent D., Allo, Patrick., Taddeo, Mariarosaria, Wachter, Sandra and Floridi, Luciano (2016), The ethics of algorithms: Mapping the debate, Big Data \& Society, 3(2), https://journals.sagepub.com/doi/ pdf/10.1177/2053951716679679 (accessed: 26 April 2020). 
Over the last few years, there has been a growing interest in algorithm ethics. Nevertheless, research shows that algorithm ethics is failing in many cases since deviations from the various codes of ethics have no legal consequences ${ }^{31}$.

\section{Conclusion}

It has been observed that the most dangerous risks for humanity arise from the technologies' interdependencies. The emergence of these risks may reflect both systemic causality and limitations of available information and human analytical ability $^{32}$.

It should not, however, be underestimated that digital technology can lead to an unequal distribution of political power and unequal means to steer collective actions.

This article has illustrated the importance of crowd-based applications for improving peoples' livability. It also introduced some considerations on the effects of big-data analytics on public policy.

Innovative means should be found to overcome the risk of media control and partisanship in media information.

Research should also be concerned with the collection and governance of data. The use of online participatory decision-making processes should be legally justified. New forms of regulatory tools should experimented, and their legal basis and transparency should be demonstrated.

\section{References}

Acquisti, Alessandro, Taylor, Curtis and Wagman, Liad (2016), The economics of privacy, Journal of Economic Literature, 52 (2), 442-492.

Belleflamme, Paul, Lambert, Thomas and Schwienbacher, Armin (July 9, 2013), Crowdfunding: Tapping the Right Crowd, Journal of Business Venturing, https://ssrn.com/abstract=1836873 (accessed: 13 February 2020).

Bennett, Colin J. and Raab, Charles D. (2017), The governance of privacy: Policy instruments in global perspective, Routledge.

Brabham, Daren C. (2008), Moving the crowd at iStockphoto: The composition of the crowd and motivations for participation in a crowdsourcing application, First Monday, 13(6), https://firstmonday. org/article/\%20view/2159/1969 (accessed: 13 February 2020).

31 Hagendorff, Thilo (2020), The ethics of Ai ethics: An evaluation of guidelines, Minds and Machines, 1-22, https://link.springer.com/article/10.1007/s11023-020-09517-8 (accessed: 26 April 2020.).

32 Centeno, Miguel A., Nag, Manish, Patterson, Thayer S., Shaver, Andrew and Windawi, Jason A. (2015), The emergence of global systemic risk, Annual Review of Sociology, 41, 65-85. 
Centeno, Miguel A., Nag, Manish, Patterson, Thayer S., Shaver, Andrew and Windawi, Jason A. (2015), The emergence of global systemic risk, Annual Review of Sociology, 41, 65-85.

Clement, Grace (1989), Is the Moral Point of View Monological or Dialogical?: The Kantian Background of Habermas's Discourse Ethics, Philosophy Today, 33(2), 159-173.

Hagendorff, Thilo (2020), The ethics of Ai ethics: An evaluation of guidelines, Minds and Machines, 1-22, https://link.springer.com/article/10.1007/s11023-020-09517-8 (accessed: 26 April 2020.).

Hossain, Mokter \& Kauranen, Ilkka (2015), Crowdsourcing: a comprehensive literature review, Strategic Outsourcing: An International Journal, 8(1), 2-22.

Howe, Jeff (2006), The rise of crowdsourcing, Wired magazine, 14(6), pp. 1-4.

Irwin, Terence (2020), Ethics Through History: An Introduction, Oxford University Press.

Kant, Immanuel (2001), Lectures on ethics (Vol. 2), Cambridge University Press.

Kruse, Amy A. and Dylan D. Schmorrow (2005), Session overview: Foundations of augmented cognition, Foundations of augmented cognition, 441-445.

Loukis, Euripidis, Charalabidis, Yannis and Androutsopoulou, Aggeliki (August 2015), Evaluating a Passive social media citizensourcing innovation, In International Conference on Electronic Government, 305320, Springer, Cham.

Ludington, Sarah (2006), Reining in the data traders: A tort for the misuse of personal information, $M d$. $L$. Rev., 66, 140. https://digitalcommons.law.umaryland.edu/cgi/viewcontent.cgi?referer=https://scholar. google.com/\&httpsredir=1 \&article=3291\&context=mlr (accessed: 23 February 2020).

Marzano, Gilberto and Hadzialic, Sabahaudin (2018), Crowd participation in urban decision making and planning: an extensive urban crowdsourcing literature review, in: Conference: XVII International Conference Trends, Technological Innovation, and Digitalization in Transport, Ecology, and Logistics in Sustainable Development Functions, Travnik, 160-168.

McCarthy, George E. (2017), Marx and Social Justice: Ethics and Natural Law in the Critique of Political Economy, Brill.

Mittelstadt, Brent D., Allo, Patrick., Taddeo, Mariarosaria, Wachter, Sandra and Floridi, Luciano (2016), The ethics of algorithms: Mapping the debate, Big Data \& Society, 3(2), https://journals.sagepub.com/ doi/pdf/10.1177/2053951716679679 (accessed: 26 April 2020).

Mota, Vinicius F., Silva, Thiago H., Macedo, Daniel F., Ghamri-Doudane, Yacine and Nogueira, José M. (2018), Towards scalable mobile crowdsensing through device-to-device communication, Journal of Network and Computer Applications, 122, 99-106.

Pedersen, Jay, Kocsis, David, Tripathi, Abhishek, Tarrell, Alvin, Weerakoon, Aruna, Tahmasbi, Nargess, ... and De Vreede, Gert J. (January 2013), Conceptual foundations of crowdsourcing: A review of IS research, in: 2013 46th Hawaii International Conference on System Sciences, 579-588. IEEE.

Puaschunder, Julia M. (April 2018), Nudgital: Critique of behavioral political economy, in: Proceedings of the 9th International RAIS Conference on Social Sciences and Humanities, 87-117, https://www.ceeol. $\mathrm{com} /$ search/chapter-detail?id=661825 (accessed: 11 February 2020).

Schmidthuber, Lisa and Hilgers, Dennis (2018), Unleashing innovation beyond organizational boundaries: exploring citizensourcing projects, International Journal of Public Administration, 41(4), 268-283.

Schmorrow, Dilan D. and Fidopiastis, Cali M., eds., (2018), Augmented Cognition: Intelligent Technologies: 12th International Conference, AC 2018, Held as Part of HCI International 2018, Las Vegas, NV, USA, July 15-20, 2018, Proceedings (Vol. 10915), Springer.

Schwartz, Paul M. (2004), Property, privacy, and personal data, Harvard Law Review, 2056-2128.

Stanney, Kay M., Schmorrow, Dylan D., Johnston, Matthew, Fuchs Sven, Jones, David, Hale, Kelly S., Ahmad, Ali and Young Peter (2009), Augmented cognition: An overview, Reviews of human factors and ergonomics, 5(1), 195-224.

Tamilin, Andrei, Carreras, Iacopo, Ssebaggala, Emmanuel, Opira, Alfonse and Conci, Nicola (September 2012), Context-aware mobile crowdsourcing, in: Proceedings of the 2012 ACM Conference on Ubiquitous Computing, 717-720. 
Taylor, James S., eds., (2005), Personal autonomy: New essays on personal autonomy and its role in contemporary moral philosophy, Cambridge University Press.

Thapa, Basanta E., Niehaves, Bjorn, Sedel, Claudius E., \& Plattfaut, Ralf (2015), Citizen involvement in public sector innovation: Government and citizen perspectives, Information Polity, 20(1), 3-17.

Timberg, Craig \& Hamburger, Tom (March 25, 2018), Former Cambridge Analytica workers say firm sent foreigners to advise U.S. campaigns, Washington Post, https://www.washingtonpost.com/politics/formercambridge-analytica-workers-say-firm-sent-foreigners-to-advise-us-campaigns/2018/03/25/6a0d7d902fa2-11e8-911f-ca7f68bff0fc_story.html?utm_term=.420bc7a15e33 (accessed: 13 February 2020).

You, Linlin, Motta, Gianmario, Liu, Kaixu, and Ma, Tianyi (2016), City feed: A pilot system of citizen-sourcing for city issue management, ACM Transactions on Intelligent Systems and Technology (TIST), 7(4), 1-25.

Yu, Po-Lung (2013), Multiple-criteria decision making: concepts, techniques, and extensions (Vol. 30), Springer Science \& Business Media.

Warnock, Geoffrey J. (1974), Contemporary moral philosophy, in: Hudson William D. New Studies in Ethics, Palgrave, 421-503.

Zheng, Haichao, Li, Dahui, \& Hou, Wenhua (2011), Task design, motivation, and participation in crowdsourcing contests, International Journal of Electronic Commerce, 15(4), 57-88.

Zhilin, Sergei., Klievink, Bram, and de Jong, Martin (2019), Community Self-Governance in the Smart City: Towards a Typology, in: E-Participation in Smart Cities: Technologies and Models of Governance for Citizen Engagement, Springer, Cham, 81-97. 


\section{Aplikacije utemeljene na mnoštvu i društveni izazovi}

\section{SAŽETAK}

Širenje mobilne tehnologije i sveprisutna povezanost otvorili su velike mogućnosti za upotrebu aplikacija koje iskorištavaju podatke generirane normalnim interakcijama korisnika na webu. Kao posljedica toga, sve je veći interes za aplikacije utemeljene na mnoštvu (engl. crowd-based applications), za one programe koji uključuju ljude na participativni ili oportunistički način. U mnogim se slučajevima podaci mogu prikupljati automatski, bez djelovanja korisnika, a u nekim slučajevima čak i bez njihova izričitog znanja. Mogućnost izbjegavanja svjesnosti korisnika potiče zabrinutosti u vezi s potencijalnim rizicima koji su skriveni u aplikacijama utemeljenim na mnoštvu. Te aplikacije mogu ugroziti privatnost građana, dok bi se prikupljeni podaci mogli koristiti za manipuliranje stavovima ljudi. Upravljanje tehnologijom kontroverzno je područje i o tom pitanju postoji mnoštvo različitih stajališta. Neki dogmatski zastupaju pozitivne vrijednosti tehnologije, dok drugi digitalni napredak tumače kao distopijsku prijetnju. Rad se usredotočuje na aplikacije utemeljene na mnoštvu, ističući neke društvene izazove i rizike koje mogu predstavljati. Tehnologija napreduje tako brzo da je izazovno biti u tijeku s promjenama koje je donijela digitalna revolucija. No, potrebno je pokušati produbiti digitalno znanje građana i uključiti ih u upotrebu novih tehnologija, a u tom je poduhvatu veće znanje temeljni korak u svakom kritičnom procesu.

Ključne riječi: privatnost građana, aplikacija temeljena na mnoštvu (crowd-based application), masovno prikupljanje (crowdsourcing), suradno opažanje (crowdsensing), građansko opažanje (citizensensing), društveni izazovi. 